\title{
Multicystic Dysplastic Kidney: Four-Year Evaluation
}

\author{
Multikistik Displastik Böbrek: Dört Yıllık Inceleme
}

\author{
Berna AYTAÇ', İbrahim ŞEHITOĞLU', Hakan VURUSKAN²
}

Departments of ${ }^{1}$ Pathology and ${ }^{2}$ Urology, Uludağ University, Faculty of Medicine, BURSA, TURKEY

\begin{abstract}
Objective: Multicystic dysplastic kidney is a relatively common developmental abnormality in infants and children. Additional abnormalities like vesicoureteral reflux, ureteropelvic junction obstruction, and ureterovesical junction obstruction may accompany multicystic dysplastic kidney. In this article, we reviewed the pathogenesis, diagnosis, associated urinary tract anomalies and results of management of multicystic dysplastic kidney in the light of the literature.

Material and Method: We retrospectively assessed 20 children with unilateral multicystic dysplastic kidney between January 2005 and December 2009. Mean duration of follow-up was $35 \pm 8.7$ months. All children with multicystic dysplastic kidney underwent nephrectomy. Patient characteristics, the pathology findings, associated urinary tract anomalies and results of management were reviewed.
\end{abstract}

Results: Abdominal ultrasound, voiding cystourethrography and renal scintigraphy revealed vesicoureteral reflux in 3 (15\%) children, ureteropelvic junction obstruction in $3(15 \%)$ children, and a duplex system in the contralateral kidney in 1 (5\%) child. Blood pressure values, serum urea, creatinine and urinalysis were within normal range in all children during follow-up.

Conclusion: A conservative approach to children with multicystic dysplastic kidney has been advocated, but surgical removal is also another management modality on the basis of risk of hypertension, mass effect, potential for malignant change, and cost of repeated ultrasound examination.

Key Words: Multicystic dysplastic kidney, Multicystic renal dysplasia

\section{ÖZ}

Amaç: Multikistik displastik böbrek yenidoğan ve çocuklarda sık olarak görülen bir gelişim anomalisidir. Vezikoüreteral reflü, üreteropelvik ve üreterovezikal bileşke obstrüksiyonu gibi diğer anomaliler multikistik displastik böbreğe eşlik edebilir. Bu makalede amacımız multikistik displastik böbrekli hastaların patogenezini, tanısını, ilişkili olduğu üriner sistem anomalilerini ve klinik sonuçlarını literatür bilgileri ışı̆̆ında tekrar gözden geçirmektir.

Gereç ve Yöntem: Ocak 2005- Aralık 2009 tarihleri arasında, geriye dönük olarak tek taraflı multikistik displastik böbreğe sahip 20 çocuk değerlendirildi. Ortalama takip süreleri $35 \pm 8,7$ aydi. Multikistik displastik böbrekli tüm çocuklara nefrektomi yapılmıştı. Hastaların özellikleri, patolojik bulguları, eşlik eden üriner sistem anomalileri ve klinik sonuçları gözden geçirildi.

Bulgular: Abdominal ultrasonografi, voiding sistoüretrografi ve renal sintigrafi yoluyla diğer böbrekte, 3 çocukta (\%15) vezikoüreteral reflü, 3 çocukta (\%15) üreteropelvik bileşke obstrüksiyonu ve 1 çocukta (\%5) çift sistem saptand. Takipler sırasında tüm çocuklarda kan basınc1, serum üre, kreatinin değerleri ve idrar analizi normal sinırlarda bulundu.

Sonuç: Multikistik displastik böbrekli çocuklarda konservatif tedavi yaklaşımı savunulmaktadır. Ancak hipertansiyon riski, kitle etkisi, malign değişim potansiyeli ve tekrarlanan ultrasonografi maliyeti göz önüne alındığında cerrahi tedavi diğer bir tedavi seçeneği de olabilir.

Anahtar Sözcükler: Multikistik displastik böbrek, Multikistik renal displazi

\section{INTRODUCTION}

Multicystic dysplastic kidney (MCDK), a variant of renal dysplasia, is one of the most frequently identified congenital urinary tract abnormalities. The incidence varies, depending on the study and country, but ranges from 1 in 3,640 to 4,300 live births (1-4). MCDK can be familial disease but most often occurs as a sporadic finding (5). Prenatal ultrasound (US) scans detect $77-88 \%$ of MCDK cases (6). They are

Received : 06.01.2011

Accepted : 20.03.2011 more commonly diagnosed in boys and usually found on the left side but may also be bilateral $(7,8)$. Most commonly found additional abnormalities in patients with MCDK include vesicoureteral reflux (VUR), ureteropelvic junction (UPJ) obstruction, and ureterovesical junction obstruction $(6,8,9)$. In this article we reviewed the pathogenesis, diagnosis, associated urinary tract anomalies and results of management of MCDK in light of the literature.

Correspondence: Berna AYTAÇ

Department of Pathology, Uludağ University, Faculty of Medicine,

BURSA, TURKEY

E-mail: berbun@gmail.com Phone: +90 2242950000 


\section{MATERIAL and METHODS}

We retrospectively assessed 20 children (2 girls and 18 boys) with unilateral MCDK between January 2005 and December 2009. The age of children admitted to our center

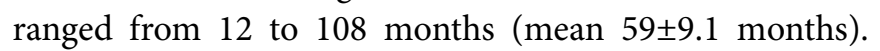
Mean duration of follow-up was $35 \pm 8.7$ months (range 1260 months). The first complaint of patients at admission was abdominal mass. Urinary tract malformation was suspected in prenatal ultrasound tests in $4(20 \%)$ children. US performed after birth revealed MCDK in 20 children. Indications for US included urinary tract infection and incidental study. US examinations were repeated every 6 months after the diagnosis. All patients underwent voiding cystourethrography (VCUG). Renal scintigraphy was performed with technetium-99m, dimercaptosuccinic

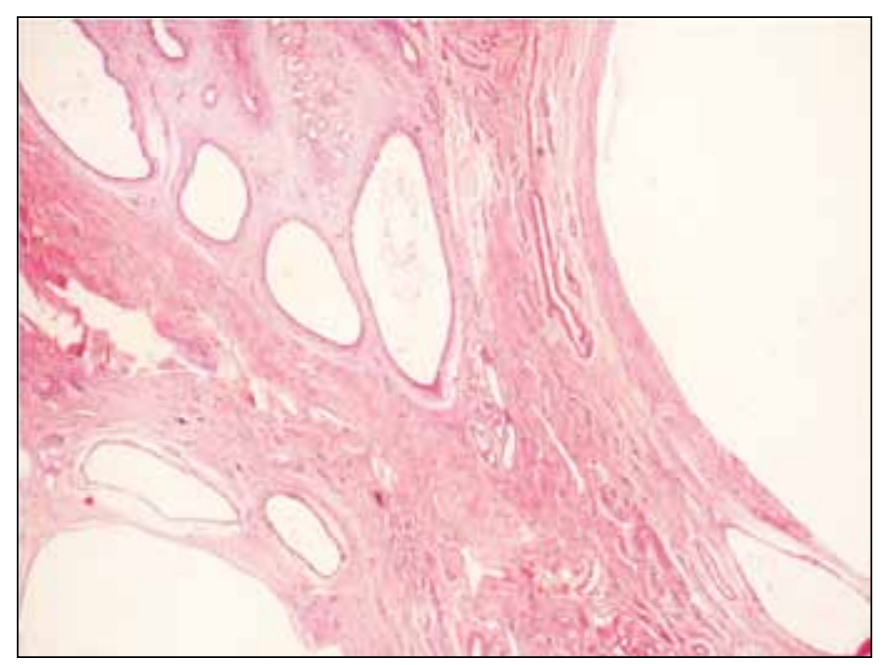

Figure 1: Dysplastic kidney containing multiple cysts (H\&E; $\mathrm{x} 100)$.

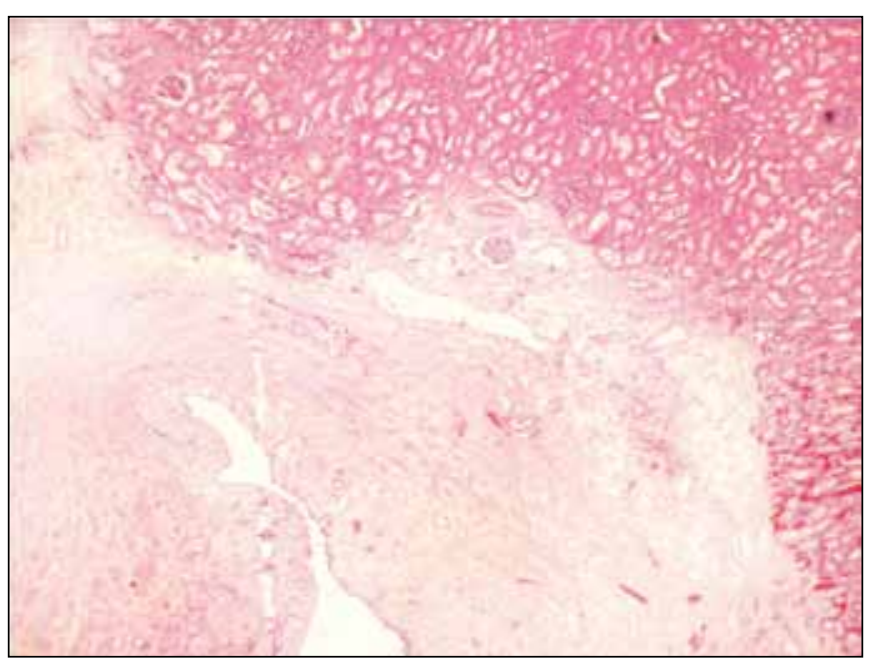

Figure 2: Aberrantly formed glomeruli (H\&E; x40). acid (99mTc-DMSA) to confirm MCDK and evaluate renal scarring in the contralateral kidney. Blood pressure was measured in all children; additionally serum urea and creatinine measurements, as well as urinalysis and urine culture were performed at baseline and periodically repeated thereafter. The presence of urological anomalies in children with MCDK was an indication for antimicrobial prophylaxis (with nitrofurantoin or trimethoprim). For histopathological evaluation, whole-mount sections of one side of the kidneys were examined. Tissue samples were processed routinely and fixed in $10 \%$ formalin solution and embedded in paraffin. Tissue sections of $3 \mu \mathrm{m}$ were obtained and stained with hematoxylin and eosin (H\&E). Histopathological examinations were performed under the light microscope.

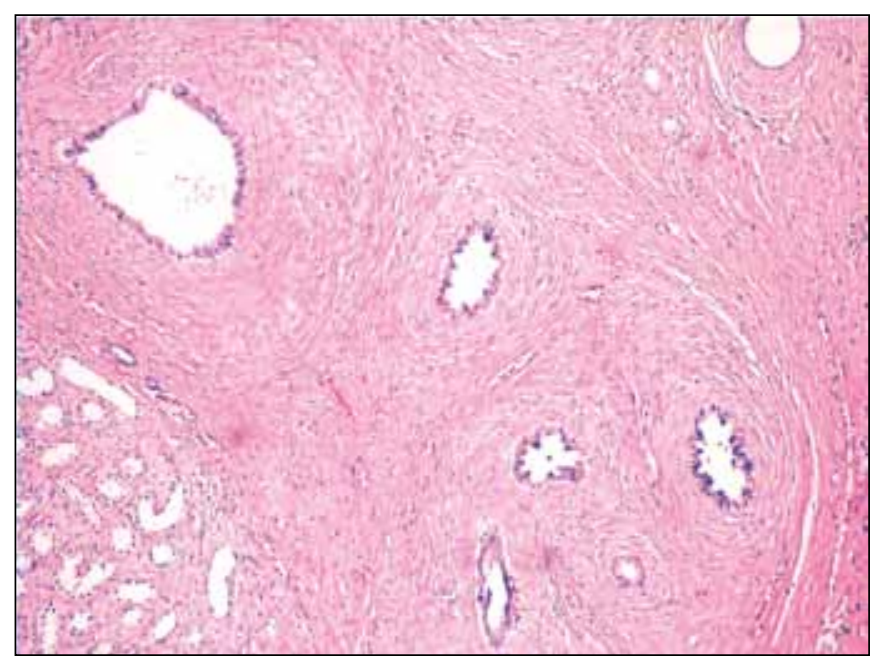

Figure 3: Primitive-appearing tubules surrounded by condensed mesenchymal cells (H\&E; x100).

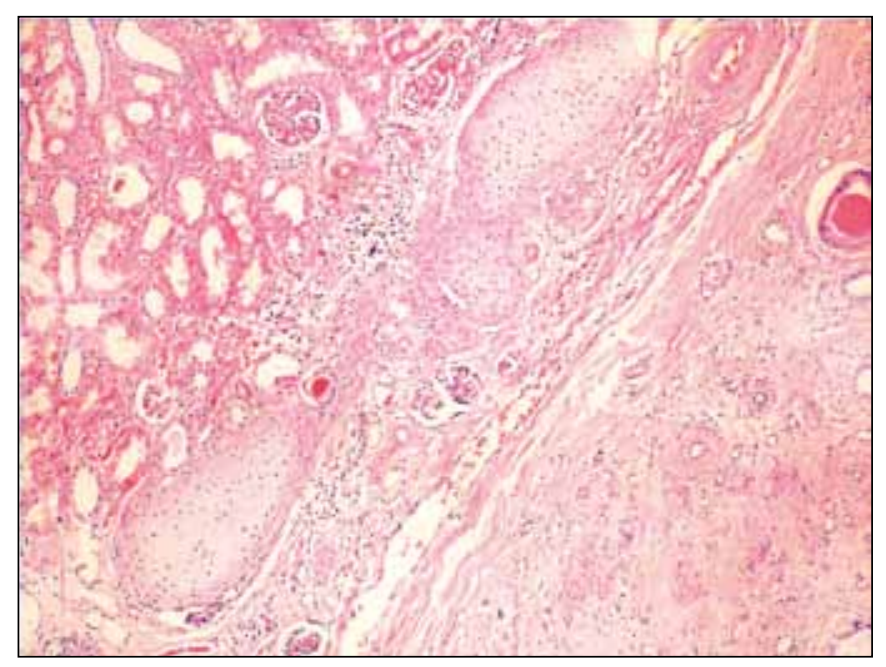

Figure 4: Cartilage within dysplastic kidney (H\&E; x100). 


\section{RESULTS}

MCDK was diagnosed in the left side in $12(60 \%)$ and the right side in 8 (40\%) children. Abdominal US, VCUG and renal scintigraphy revealed VUR in 3 (15\%) children, UPJ stenosis in 3 (15\%) children and a duplex system in the contralateral kidney in 1 (5\%) child. Antimicrobial prophylaxis was applied in ten children. Indication for antimicrobial prophylaxis included VUR in 3 children, UPJ stenosis in 3 (15\%) children, urinary tract infection in 3 (15\%) children and a duplex system in $1(5 \%)$ child. Among the 7 (35\%) children with urological anomalies accompanying MCDK, 1 (5\%) child underwent dismembered pyeloplasty. The remaining $6(30 \%)$ children were treated conservatively.

All children with MCDK underwent nephrectomy in this series. The indication for nephrectomy was hypertension in 4 patients, abdominal mass in 6 patients, and recurrent urinary infection in other patients. The diagnosis of MCDK was confirmed by histopathology in all children who underwent nephrectomy. Histopathologically, variably sized cysts replaced the renal parenchyma in the sections. Characteristically, large cysts were lined by flattened cuboidal epithelium (Figure 1) and an intervening parenchyma that was fibrotic with islands of cartilage and rare glomeruli. Frequently glomeruli appeared immature and aberrantly formed (Figure 2). Primitive or dysplastic ducts were lined with columnar epithelium and surrounded by collars of spindle cells (Figure 3). Immature cartilage was seen (Figure 4). Blood pressure values, serum urea, creatinine and urinalysis were within normal range in all children.

\section{DISCUSSION}

Multicystic dysplastic kidney (MCDK) is characterized by replacement of normal kidney tissue with numerous cysts, undifferentiated epithelium and primitive ducts surrounded by fibromuscular connective tissue $(2,10,11)$. This malformation results from abnormal metanephros differentiation, probably due to disturbed connection of ureteric bud with renal blastema and abnormal division at the stage of metanephros $(2,10,12,13)$.

Various etiological factors have been held responsible for MCDK. Teratogens, such as in utero viral infections and medications, have also been implicated. In one study, $1-3 \%$ of children with congenital kidney malformations had amniotic fluid that produced cultures positive for enterovirus, cytomegalovirus or adenovirus (14). A series of four infants with MCDK and epileptic mothers treated during pregnancy with antiepileptic drugs raises the possibility that medications may be a contributing factor (15).
Many concurrent urinary tract abnormalities have been described in patients with MCDK. The most common and potentially significant urologic defect seen is VUR to the contralateral kidney. The largest study, with 143 patients that underwent a VCUG, describes a VUR incidence of $19 \%$ to the contralateral kidney and $16 \%$ to the MCDK (1). Contralateral VUR was seen in $15 \%$ of the children in our series. Other urinary tract abnormalities, such as contralateral UPJ obstruction are often seen in patients with MCDK. In our series, contralateral UPJ obstruction was seen in $15 \%$ of the children. According to the literature it has been described in $7-15 \%$ of individuals with MCDK (16).

The natural history is unclear and many studies have shown that MCDK tends to involute. Complete involution rates vary from $19-74 \%$ over 9 months to 10 years. This involution may be so severe that the affected kidney disappears in subsequent sonograms $(1,17)$. In patients with complete MCDK involution, $92 \%$ had compensatory hypertrophy of the contralateral kidney (18). In one long-term, prospective study of 33 children with a MCDK, $24 \%$ had compensatory hypertrophy at birth, and 52\% demonstrated compensatory hypertrophy in later childhood, with a mean follow-up duration of 4.9 years (19).

Another management question in MCDK disease is frequency of hypertension and has been provided as a reason for nephrectomy of the affected kidney $(20,21)$. Furthermore, case reports have described how MCDK patients with hypertension were cured by nephrectomy of the involved kidney (22). In a study of 887 patients with MCDK, only $6(0.7 \%)$ had hypertension (23). In another series of 20 patients older than 11 years who had MCDK, only 2 had hypertension and the blood pressure was not controlled by nephrectomy in these patients (22).

Of greater concern is the potential for malignant degeneration in a MCDK. Most case reports have been of Wilms tumor, renal cell carcinoma and urothelial carcinomas that developed in a MCDK $(25,26)$. The incidence of Wilms tumor developing in MCDK is greater than fourfold, citing an incidence of 1 in 8000 general population and 1 in 2000 in the MCDK population. This fourfold increase does not make a case for prophylactic nephrectomy (27). In our series there were no patients with malignant degeneration. Flank pain as an adult is another risk of MCDK that is left in situ, and in such cases the pain usually responds to nephrectomy (23). This was the main indication for nephrectomy in our series. 
Identification of MCDK in newborns has dramatically increased with the use of fetal ultrasound (28). If MCDK is suspected on prenatal ultrasound, a postnatal ultrasound will confirm the diagnosis and screen for other urinary tract abnormalities (29). Recent improvements regarding the natural history of MCDK, especially with regard to prenatal diagnosis and conservative management, have changed the approach to this anomaly. Until the mid1980s, the management of MCDK patients often consisted of nephrectomy. Since then, with the improvements in fetal US, such management has been replaced by clinical and sonographic follow-up of the patients. Some studies have shown that conservative management seems to be a safe option; the prevalence of complications is negligible and most of the affected units have partial or complete involution on US. Recently, a comparative study between surgical and conservative treatments has not revealed any significant difference in the frequency of complications for the patients (30).

A conservative approach to children with MCDK has been advocated, but others have suggested surgical removal on the basis of risk of hypertension, mass effect, potential for malignant change, and cost of repeated US examination. According to our experience, the conservative approach is a reliable method for patients who can attend regular followup. Nephrectomy can be undertaken if any complication occurs. Children with MCDK therefore need a protocol of initial investigation and regular follow-up, even if the MCDK is removed, to determine the growth and function of the contralateral kidney.

\section{REFERENCES}

1. Aslam M, Watson AR: Trent \& Anglia MCDK Study Group: Unilateral multicystic dysplastic kidney: long term outcomes. Arch Dis Child 2006, 91:820-823

2. Krzemień G, Roszkowska-Blaim M, Kostro I, Wojnar J, Karpińska M, Sekowska R: Urological anomalies in children with renal agenesis or multicystic dysplastic kidney. J Appl Genet 2006, 47:171-176

3. Psooy K: Long-term urological follow-up of multicystic dysplastic kidneys: Is it still indicated in 2007? Can Urol Assoc J 2007, 1: 113-116

4. Feldenberg LR, Siegel NJ: Clinical course and outcome for children with multicystic dysplastic kidneys. Pediatr Nephrol 2000, 14:1098-1101

5. Belk RA, Thomas DF, Mueller RF, Godbole P, Markham AF, Weston MJ: A family study and the natural history of prenatally detected unilateral multicystic dysplastic kidney. J Urol 2002, 167:666-669

6. Ylinen E, Ahonen S, Ala-Houhala M, Wikström S: Nephrectomy for multicystic dysplastic kidney: if and when? Urology 2004, 63: $768-771$
7. Cascio S, Paran S, Puri P: Associated urological anomalies in children with unilateral renal agenesis. J Urol 1999, 162: 1081-1083

8. Kaneyama K, Yamataka A, Satake S, Yanai T, Lane GJ, Kaneko K, Yamashiro Y, Miyano T: Associated urologic anomalies in children with solitary kidney. J Pediatr Surg 2004, 39: 85-87

9. Abidari JM, Park KH, Kennedy WA, Shortliffe LD: Serial followup of the contralateral renal size in children with multicystic dysplastic kidney. J Urol 2002, 168: 1821-1825

10. al-Khaldi N, Watson AR, Zuccollo J, Twining P, Rose DH: Outcome of antenatally detected cystic dysplastic kidney disease. Arch Dis Child 1994, 70:520-522

11. Kohaut EC, Tejani A: The 1994 annual report of the North American Pediatric Renal Transplant Cooperative Study. Pediatr Nephrol 1996, 10:422-434

12. Mackie GG, Stephens FD: Duplex kidneys: a correlation of renal dysplasia with position of the ureteral orifice. J Urol 1975, 114:274-280

13. Viana R, Batourina E, Huang H, Dressler GR, Kobayashi A, Behringer RR, Shapiro E, Hensle T, Lambert S, Mendelsohn C: The development of the bladder trigone, the center of the antireflux mechanism. Development 2007, 134:3763-3769

14. Petrikovsky BM, Lipson SM, Kaplan MH: Viral studies on amniotic fluid from fetuses with and without abnormalities detected by prenatal sonography. J Reprod Med 2003, 48:230-232

15. Carta M, Cimador M, Giuffrè M, Sergio M, Di Pace MR, De Grazia E, Corsello G: Unilateral multicystic dysplastic kidney in infants exposed to antiepileptic drugs during pregnancy. Pediatr Nephrol 2007, 22:1054-1057

16. Rahman RC, Amoreo O: Multicystic dysplastic kidney: diagnosis and evolution. Pediatr Nephrol 2005, 20:1023

17. Wacksman J, Phipps L: Report of the Multicystic Kidney Registry: preliminary findings. J Urol 1993, 150:1870-1872

18. Onal B, Kogan BA: Natural history of patients with multicystic dysplastic kidney-what followup is needed? J Urol 2006, 176:1607-1611

19. John U, Rudnik-Schöneborn S, Zerres K, Misselwitz J: Kidney growth and renal function in unilateral multicystic dysplastic kidney disease. Pediatr Nephrol 1998, 12:567-571

20. Oliveira EA, Silva AC, Rabelo EA, Filgueiras FF, Pereira AK, Mesquita FM: Spontaneous improvement of hypertension in multicystic dysplastic kidney: a case report. Pediatr Nephrol 2002, 17:954-958

21. Konda R, Sato H, Ito S, Sakai K, Kimura N, Nagura H: Renin containing cells are present predominantly in scarred areas but not in dysplastic regions in multicystic dysplastic kidney. J Urol 2001, 166:1910-1914

22. Angermeier KW, Kay R, Levin H: Hypertension as a complication of multicystic dysplastic kidney. Urology 1992, 39:55-58

23. Kenneth IG: Renal disgenesis and cystic disease of the kidney. In Wein AJ, Kavoussi LR, Novick AC, Partin AW, Peters CA (Eds): Campbell-Walsh Urology, 9th ed., Philadelphia, Elsevier, 2007, 3305-3358

24. Ambrose SS: Unilateral multicystic renal disease in adults. Birth Defects Orig Artic Ser 1977, 13:349-353 
25. Mingin GC, Gilhooly P, Sadeghi-Nejad H: Transitional cell carcinoma in a multicystic dysplastic kidney. J Urol 2000, 163:544

26. Rackley RR, Angermeier KW, Levin H, Pontes JE, Kay R: Renal cell carcinoma arising in a regressed multicystic dysplastic kidney. J Urol 1994, 152:1543-1545

27. Beckwith JB: New developments in the pathology of Wilms tumor. Cancer Invest 1997, 15:153-162

28. Oliveira EA, Diniz JS, Vilasboas AS, Rabêlo EA, Silva JM, Filgueiras MT: Multicystic dysplastic kidney detected by fetal sonography: conservative management and follow-up. Pediatr Surg Int 2001, 17:54-57
29. Zhou Q, Ji ZZ, Cardoza J: Value of ultrasound in the diagnosis of congenital renal malformations. Di Yi Jun Yi Da Xue Xue Bao 2005, 25:1086-1089

30. Rabêlo EA, Oliveira EA, Silva JM, Bouzada MC, Sousa BC, Almeida MN, Tatsuo ES: Conservative management of multicystic dysplastic kidney: clinical course and ultrasound outcome. J Pediatr (Rio J) 2005, 81:400-404 